University of Nebraska - Lincoln

DigitalCommons@University of Nebraska - Lincoln

2008

\title{
Reduction of Tc(VII) by Fe(II) Sorbed on Al (hydr)oxides
}

T. Peretyazhko

Pacific Northwest National Laboratory, tetyana.peretyazhko@pnl.gov

J.M. Zachara

Pacific Northwest National Laboratory

S.M. Heald

Argonne National Laboratory

Ravi K. Kukkadapu

Pacific Northwest National Laboratory, ravi.kukkadapu@pnl.gov

C. Liu

Pacific Northwest National Laboratory

See next page for additional authors

Follow this and additional works at: https://digitalcommons.unl.edu/usdoepub

Part of the Bioresource and Agricultural Engineering Commons

Peretyazhko, T.; Zachara, J.M.; Heald, S.M.; Kukkadapu, Ravi K.; Liu, C.; Plymale, A.E.; and Resch, C.T., "Reduction of Tc(VII) by Fe(II) Sorbed on Al (hydr)oxides" (2008). US Department of Energy Publications. 150.

https://digitalcommons.unl.edu/usdoepub/150

This Article is brought to you for free and open access by the U.S. Department of Energy at DigitalCommons@University of Nebraska - Lincoln. It has been accepted for inclusion in US Department of Energy Publications by an authorized administrator of DigitalCommons@University of Nebraska - Lincoln. 


\section{Authors}

T. Peretyazhko, J.M. Zachara, S.M. Heald, Ravi K. Kukkadapu, C. Liu, A.E. Plymale, and C.T. Resch 
Reduction of Tc(VII) by Fe(II) Sorbed on Al (hydr)oxides

\author{
T. PERETYAZHKO, ${ }^{*}{ }^{\dagger} \mathrm{J} . \mathrm{M}$. ZACHARA, \\ S. M. HEALD ${ }^{\ddagger}$ R. K. KUKKA D A P U , ${ }^{\dagger}$ \\ C. $\mathrm{LIU}^{\dagger}{ }^{\dagger} \mathrm{A}$. E. PLYMALE ${ }^{\dagger}$ AND \\ C. T. RE S C H ${ }^{\dagger}$ \\ Pacific Northwest National Laboratory, \\ Richland, Washington 99354, and Argonne National \\ Laboratory, Argonne, Illinois 60439
}

Received January 31, 2008. Revised manuscript received April 29, 2008. Accepted May 8, 2008.

Under oxic conditions, Tc exists as the soluble, weakly sorbing pertechnetate $\left[\mathrm{TCO}_{4}^{-}\right]$anion. The reduced form of technetium, $\mathrm{Tc}(\mathrm{IV})$, is stable in anoxic environments and is sparingly soluble as $\mathrm{TcO}_{2} \cdot n \mathrm{H}_{2} \mathrm{O}_{(\mathrm{s})}$. Here we investigate the heterogeneous reduction of $\mathrm{Tc}(\mathrm{VII})$ by $\mathrm{Fe}(\mathrm{II})$ adsorbed on $\mathrm{Al}$ (hydr)oxides [diaspore $(\alpha-\mathrm{AlOOH})$ and corundum $\left.\left(\alpha-\mathrm{Al}_{2} \mathrm{O}_{3}\right)\right]$. Experiments were performed to study the kinetics of $\mathrm{Tc}(\mathrm{VII})$ reduction, examine changes in Fe surface speciation during $\mathrm{Tc}(\mathrm{VII})$ reduction (Mössbauer spectroscopy), and identify the nature of $\mathrm{Tc}(\mathrm{IV})$-containing reaction products (X-ray absorption spectroscopy). We found that $\mathrm{Tc}(\mathrm{VII})$ was completely reduced by adsorbed $\mathrm{Fe}(\mathrm{II})$ within 11 (diaspore suspension) and 4 days (corundum suspension). Mössbauer measurements revealed that the $\mathrm{Fe}(\mathrm{II})$ signal became less intense with $\mathrm{Tc}(\mathrm{VII})$ reduction and was accompanied by an increase in the intensity of the $\mathrm{Fe}(\mathrm{III})$ doublet and magnetically ordered $\mathrm{Fe}$ (III) sextet signals. Tc-EXAFS spectroscopy revealed that the final heterogeneous redox product on corundum was similar to Tc(IV) oxyhydroxide, $\mathrm{TcO}_{2} \cdot n \mathrm{H}_{2} \mathrm{O}$.

\section{Introduction}

Technetium-99 $\left({ }^{99} \mathrm{Tc}\right)$ is a fission product of uranium-235 and plutonium-239 and is an important subsurface contaminant at nuclear reprocessing sites due to its long halflife $\left(t_{1 / 2}=2.13 \times 10^{5}\right.$ years $)$. Technetium speciation, solubility, and sorption behavior is strongly dependent on its valence state. Under oxic conditions, Tc exists as the pertechnetate, $\left[\mathrm{TcO}_{4}{ }^{-}\right]$, anion which is weakly sorbed under circumneutral and basic $\mathrm{pH}$ conditions (1). The reduced form of technetium, $\mathrm{Tc}(\mathrm{IV})$, is stable in anoxic environments, and in the absence of complexing ligands (carbonates, humic acids), Tc(IV) forms a sparingly soluble precipitate $\mathrm{TcO}_{2} \cdot n \mathrm{H}_{2} \mathrm{O}(2,3)$. Therefore, Tc redox transformations are crucial in controlling its migration in subsurface environments, and Tc(VII) reduction to Tc(IV) could be an efficient approach for technetium immobilization.

In anoxic subsurface environments, $\mathrm{Fe}$ (II) is an important reductant that might affect the distribution and mobility of technetium. Technetium(VII) reduction occurs in anoxic sediments and soils during microbial Fe(III) reduction that generates particulate (sorbed) and dissolved Fe(II) (1, 4-7).

\footnotetext{
* Corresponding author phone: (509) 376-1529; fax: (509) 3763650; e-mail: tetyana.peretyazhko@pnl.gov.

${ }^{\dagger}$ Pacific Northwest National Laboratory.

${ }^{\ddagger}$ Argonne National Laboratory.
}

Homogeneous Tc(VII) reduction by aqueous $\mathrm{Fe}(\mathrm{II})$ has been considered an improbable process although it is thermodynamically feasible $(6,8)$. A recent study by Zachara et al. (9) demonstrated that $\mathrm{Tc}(\mathrm{VII})$ reduction by dissolved Fe(II) occurred in neutral solutions by a combination of homogeneous and heterogeneous reactions. The heterogeneous reaction was more rapid and apparently promoted by $\mathrm{Fe}(\mathrm{II})$ sorbed on a mixed $\mathrm{Fe}(\mathrm{III}) / \mathrm{Tc}$ (IV) product.

Numerous studies have reported that sorbed Fe(II) is a stronger reducing agent than dissolved $\mathrm{Fe}$ (II) $(10,11)$. Iron(II) sorbed on various Fe(III) (hydr) oxides enhances the rates of reduction of inorganic and organic contaminants (ref 12 and references therein). Technetium(VII) is efficiently reduced to $\mathrm{Tc}$ (IV) by $\mathrm{Fe}(\mathrm{II})$ sorbed on synthetic and natural solids [bioreduced sediments (1, 6, 7), Fe(III) (hydr)oxides (12)], by $\mathrm{Fe}(\mathrm{II})$-containing minerals [magnetite $(13,14)$, pyrite (15), green rust (16), structural Fe(II) in clays (12)], and by Fe(II)bearing fracture material from granite (13). The pertechnetate reduction products vary from $\mathrm{TcO}_{2}$-like phases $(1,17,18)$ to Fe/Tc precipitates $(9,12,16)$.

The objectives of this research were to investigate the extent and kinetics of heterogeneous Tc(VII) reduction by $\mathrm{Fe}(\mathrm{II})$ sorbed on $\mathrm{Al}$ (hydr)oxides [diaspore $(\alpha-\mathrm{AlOOH})$ and corundum $\left(\alpha-\mathrm{Al}_{2} \mathrm{O}_{3}\right)$ ], study changes in Fe surface speciation during $\mathrm{Tc}(\mathrm{VII})$ reduction, and identify $\mathrm{Tc}(\mathrm{IV})$-containing reaction products. The aluminum (hydr)oxides chosen for study are isostructural to $\mathrm{Fe}(\mathrm{III})$ (hydr)oxides [goethite $(\alpha-$ $\mathrm{FeOOH})$ and hematite $\left.\left(\alpha-\mathrm{Fe}_{2} \mathrm{O}_{3}\right)\right]$ that are abundant in soils and sediments. Iron(II) adsorbed to Fe(III) (hydr)oxides promotes rapid heterogeneous reduction of Tc(VII) (12). Aluminum (hydr)oxides behave differently than do Fe(III) (hydr)oxides with regard to the valence stability of adsorbed $\mathrm{Fe}(\mathrm{II})$, with probable implications to Tc(VII) reduction. Adsorbed Fe(II) is oxidized at the Fe(III) (hydr)oxide interface under anoxic conditions by electron transfer with the bulk solid $(19,20)$. In contrast, adsorbed Fe(II) is valence stable at the $\alpha-\mathrm{Al}_{2} \mathrm{O}_{3}$ interface (19). Mössbauer and X-ray absorption spectroscopy were applied to reveal changes in $\mathrm{Fe}$ (II)/Fe(III) surface speciation and identify the nature of precipitated Tc(IV)-containing solid phases.

\section{Experimental Section}

Kinetic Experiments. All work was performed in $\mathrm{N}_{2} / \mathrm{H}_{2}(97 \%$ / $3 \%$ ) atmosphere inside an anaerobic chamber (MBrown $\mathrm{GmbH}$ Inc.) with oxygen concentration less than $0.1 \mathrm{ppm}$. Preliminary experiments demonstrated that dissolved Fe(II) remained valence and concentration stable under these conditions at $\mathrm{pH} 7$ during 15-day reaction time.

An aliquot of Fe(II) solution (22.75 mM) and PIPES buffer were added to $125-\mathrm{mL}$ plastic bottles (Nalgen, HDPE) to obtain a final Fe(II) concentration of $0.1 \mathrm{mM}$ in $30 \mathrm{mM}$ PIPES buffer ( $\mathrm{pH}$ 7). Three replicates were prepared for each kinetic experiment. Iron(II) concentrations were monitored for one day to ensure the stability of Fe(II) added against any oxidation or precipitation; then $\mathrm{Al}$ (hydr)oxides were added to obtain final concentrations of $3 \mathrm{~g} / \mathrm{L}$ (corundum) and $5 \mathrm{~g} / \mathrm{L}$ (diaspore) (see Supporting Information for Al (hydr)oxides characterization and preparation of the stock suspensions). Two days equilibration time was allowed for Fe(II) adsorption, and then Tc(VII) was added to the suspensions. No change in suspension $\mathrm{pH}$ was observed over experiment duration. Dissolved Fe(II), total Fe(II), and dissolved Tc(VII) concentrations were monitored over time. The conditions of the reduction experiments are summarized in Table 1. Analytical techniques are described in the Supporting Information. 
TABLE 1. Summary of Experimental Conditions and Kinetic Analyses

\begin{tabular}{|c|c|c|c|c|c|c|}
\hline & $\begin{array}{c}\text { solid } \\
\text { concentration ( } g / L)\end{array}$ & $\operatorname{Tc}(\mathrm{VII})_{\text {added }}(\mu \mathrm{M})$ & $\mathrm{Fe}(\mathrm{II})_{\text {added }}(\mathrm{mM})$ & $\begin{array}{c}\text { nominal sorbed } \\
\mathrm{Fe}(\mathrm{II})^{a}(\mathrm{mM})\end{array}$ & $k_{\mathrm{obs}}\left(\mathrm{h}^{-1}\right)$ & $\begin{array}{c}\boldsymbol{k}_{\mathrm{obs}} / \mathrm{Fe}(\mathrm{II}) \\
\text { sorbed }\end{array}$ \\
\hline diaspore & 5.0 & $10.4 \pm 0.2$ & $0.107 \pm 0.001$ & $0.029 \pm 0.001$ & 0.009 & 0.3 \\
\hline \multirow[t]{2}{*}{ corundum } & 3.0 & $10.0 \pm 0.1$ & $0.097 \pm 0.001$ & $0.040 \pm 0.003$ & 0.04 & 1.0 \\
\hline & 3.0 & $30.4 \pm 0.2$ & $0.107 \pm 0.002$ & $0.027 \pm 0.002$ & 0.05 & 1.8 \\
\hline goethite $^{b}$ & 1.5 & $10.3 \pm 0.0$ & $0.12 \pm 0.00$ & $0.070 \pm 0.002$ & $>16$ & $>228$ \\
\hline hematite $^{b}$ & 4.5 & $10.3 \pm 0.0$ & $0.12 \pm 0.00$ & $0.078 \pm 0.001$ & $>16$ & $>205$ \\
\hline
\end{tabular}

${ }^{57}$ Fe Mössbauer Spectroscopy. Mössbauer measurements were performed on ${ }^{57} \mathrm{Fe}(\mathrm{II})$ adsorbed onto corundum $(3 \mathrm{~g} / \mathrm{L}$ corundum, $0.1 \mathrm{mM}{ }^{57} \mathrm{Fe}(\mathrm{II})$ with/without 10 or $30 \mu \mathrm{M} \mathrm{Tc}(\mathrm{VII})$, $\mathrm{pH}$ 7). Reduction experiments were performed as previously described. Suspension ( $50 \mathrm{~mL}$ ) was withdrawn into a syringe, filtered $[0.45-\mu \mathrm{m}$ pore-size (Millipore)], and the filter membrane and solid were sealed in the vaseline-filled $\mathrm{Cu}$ Mössbauer disk. Mössbauer spectra were collected according to a procedure given in Zachara et al. (9).

X-ray Absorption Spectroscopy. Procedures for preparation of Tc-EXAFS standards $\left(\mathrm{TcO}_{2} \cdot n \mathrm{H}_{2} \mathrm{O}\right.$, slow and fast titrated Tc/corundum precipitates) are summarized in the Supporting Information. The postreaction suspensions [3 $\mathrm{g} / \mathrm{L}$ corundum contacted with $0.1 \mathrm{mM} \mathrm{Fe}(\mathrm{II})$ and 10 or $30 \mu \mathrm{M}$ $\mathrm{Tc}(\mathrm{VII}), \mathrm{pH}$ 7] were dried in a vacuum desiccator within an anaerobic chamber. The dried Fe/Tc/corundum precipitates and standards were packed into Delrin sample holders with a $2 \mathrm{~mm} \times 15 \mathrm{~mm} \times 6 \mathrm{~mm}$ slot, and the samples were sealed with Kapton tape ( 1 mil, CS Hyde, Co.). The samples were placed inside $100 \mathrm{~mL}$ Wheaton glass bottles and sealed for storage and shipment to the beamline. The Tc-XAS spectra were collected and analyzed according to a procedure given in Zachara et al. (9).

\section{Results}

Reduction of Tc(VII) by Sorbed Fe(II) on Diaspore and Corundum. Our control experiments [i.e., without $\mathrm{Fe}(\mathrm{II})]$ confirmed that pertechnetate, $\mathrm{TcO}_{4}{ }^{-}$, is a weakly sorbing anion at $\mathrm{pH} 7$. Sorption of $\mathrm{TcO}_{4}{ }^{-}$was $4.4 \%$ to $5 \mathrm{~g} / \mathrm{L}$ diaspore and $1 \%$ to $3 \mathrm{~g} / \mathrm{L}$ corundum (Figure $\mathrm{S} 1$ ).

Technetium(VII) reduction by Fe(II) adsorbed on diaspore occurred during 11 days of reaction time, resulting in a decrease in $\mathrm{Tc}(\mathrm{VII})_{(\mathrm{aq})}$ from 10.4 to $\sim 0.6 \mu \mathrm{M}$ (Figure 1c). The complete recovery of total $\mathrm{Fe}$ (II) before Tc(VII) addition (from -4 to 0 days) confirmed that the experimental systems were strictly anoxic (Figure 1b,e). The decrease in total Fe(II) [26 $\pm 1 \mu \mathrm{M}]$ in the diaspore suspension by the end of reaction was equal, within experimental precision, to the stoichiometric demand for reduction of Tc(VII) to Tc(IV) [Fe(II)/ $\mathrm{Tc}(\mathrm{VII})=3: 1]$. Before Tc(VII) addition, the concentration of dissolved Fe(II) dropped from 100 to $70 \mu \mathrm{M}$ because of $\mathrm{Fe}(\mathrm{II})$ adsorption on diaspore. A further decrease (to $\sim 40 \mu \mathrm{M}$ ) occurred by the eleventh day of reaction with Tc(VII) (Figure 1a). This additional $30 \mu \mathrm{M}$ decrease in dissolved Fe(II) was approximately equal to the stoichiometic concentration required for complete reduction of $\mathrm{Tc}(\mathrm{VII})$.

Technetium(VII) was completely reduced within 4 days in the corundum suspension ( $3 \mathrm{~g} / \mathrm{L}$ ) with $0.1 \mathrm{mM}$ Fe(II) (Figure 1f). This reduction was accompanied by concomitant decrease in dissolved and total Fe(II) concentrations. Dissolved $\mathrm{Fe}(\mathrm{II})$ decreased to $\sim 30 \mu \mathrm{M}$ and $<0.1 \mu \mathrm{M}$ in the presence of 10 and $30 \mu \mathrm{M} \mathrm{Tc}(\mathrm{VII})$, respectively (Figure 1d). Similar to that for the diaspore, decreases in dissolved Fe(II) occurred upon Tc(VII) addition that were proportional to the stoichiometic $\mathrm{Fe}(\mathrm{II})$ demand for Tc(VII) reduction. The total amount of $\mathrm{Fe}(\mathrm{II})$ loss was $28 \pm 3 \mu \mathrm{M}$ for $10 \mu \mathrm{M} \mathrm{Tc}(\mathrm{VII})$ addition and $65 \pm 7 \mu \mathrm{M}$ for $30 \mu \mathrm{M}$ Tc(VII) addition based on
$0.5 \mathrm{M} \mathrm{HCl}$ extraction. The total Fe(II) decrease for $10 \mu \mathrm{M}$ $\mathrm{Tc}$ (VII) reduction was equal to the stoichiometric amount of $\mathrm{Fe}(\mathrm{II})$ required for the reduction of $\mathrm{Tc}(\mathrm{VII})$ to $\mathrm{Tc}(\mathrm{IV})$, while the apparent total decrease in Fe(II) with $30 \mu \mathrm{M} \mathrm{Tc}(\mathrm{VII})$ was smaller than that value $(90 \mu \mathrm{M})$.

We hypothesized that the stoichiometric discrepancy with $30 \mu \mathrm{M}$ Tc(VII) resulted from an unexpected redox reaction between $\mathrm{Fe}(\mathrm{III})$ and $\mathrm{Tc}(\mathrm{IV})$ at acid $\mathrm{pH}$ during $\mathrm{HCl}$ extraction. Our hypothesis was confirmed by the results of TPAC (tetraphenyl arsonium chloride) extraction of Tc(VII) from the acidified suspensions. After 24-h acid extraction, a significantly higher Tc(VII) $)_{\text {TPAC }}$ concentration was measured in the corundum suspension with $30 \mu \mathrm{M}$ initial Tc(VII) concentration (Table 2). The total Fe(II) concentration at the end of $30 \mu \mathrm{M} \mathrm{Tc}(\mathrm{VII})$ reduction calculated from the $\mathrm{Tc}(\mathrm{VII})_{\mathrm{TPAC}}$ data was in good agreement with the measured one (Table 2). Therefore, redox reaction between Fe(III) and Tc(IV) at acid $\mathrm{pH}$ could explain the high total $\mathrm{Fe}(\mathrm{II})$ concentration found at the end of the Tc(VII) reduction experiment.

In all experiments, the decrease in dissolved Fe(II) after adsorption and $\mathrm{Tc}(\mathrm{VII})$ addition that paralleled $\mathrm{Tc}(\mathrm{VII})$ solution loss was equal to the stoichiometic Fe(II) demand for Tc(VII) reduction. The experiments with diaspore and corundum were designed to minimize the effect of homogeneous Tc(VII) reduction. Zachara et al. (9) demonstrated that $2-7 \%$ of $\mathrm{Tc}(\mathrm{VII})$ was homogeneously reduced after 5 days of reaction when $11 \mu \mathrm{M}$ of $\mathrm{Tc}(\mathrm{VII})$ was reacted with 0.05- $0.1 \mathrm{mM} \mathrm{Fe}(\mathrm{II})$ at $\mathrm{pH}$ 7. On the basis of these observations, we maintained the dissolved Fe(II) concentration in the heterogeneous experiments at $\leq 0.08 \mathrm{mM}$. Because adsorbed Fe(II) was the primary reductant, the stoichiometric uptake of dissolved Fe(II) upon reaction with Tc(VII) was significant. Similar to our results, Colon et al. (21) observed stoichiometric consumption of dissolved Fe(II) (electron mass balance of $\geq 90 \%$ ) during the heterogeneous reduction of nitroaromatics by adsorbed $\mathrm{Fe}(\mathrm{II})$ on goethite at $\mathrm{pH}$ 6.8. We found linear correlations between concentrations of readsorbed Fe(II) [difference between added Fe(II) and dissolved $\mathrm{Fe}(\mathrm{II})$ ] and Tc(IV) [difference between added Tc(VII) and dissolved Tc(VII)] in the diaspore suspension (eq 1) and the corundum suspensions with 10 (eq 2) and $30 \mu \mathrm{M} \mathrm{Tc}(\mathrm{VII})$ (eq 3)

$[\mathrm{Fe}(\mathrm{II})]_{\text {readsorbed }}=30.8( \pm 1.8)+2.9( \pm 0.4)[\mathrm{Tc}(\mathrm{IV})] \quad R^{2}=0.892$

$[\mathrm{Fe}(\mathrm{II})]_{\text {readsorbed }}=34.2( \pm 2.2)+3.5( \pm 0.3)[\mathrm{Tc}(\mathrm{IV})] \quad R^{2}=0.955$

$[\mathrm{Fe}(\mathrm{II})]_{\text {readsorbed }}=29.1( \pm 1.1)+2.5( \pm 0.1)[\mathrm{Tc}(\mathrm{IV})] \quad R^{2}=0.996$

The concentration of adsorbed Fe(II) [difference between total $\mathrm{Fe}(\mathrm{II})$ and dissolved $\mathrm{Fe}(\mathrm{II})]$ remained constant during reduction reaction in all samples (data not shown), because oxidized, adsorbed Fe(II) was regenerated through continued adsorption of $\mathrm{Fe}(\mathrm{III})_{(\mathrm{aq})}$. 

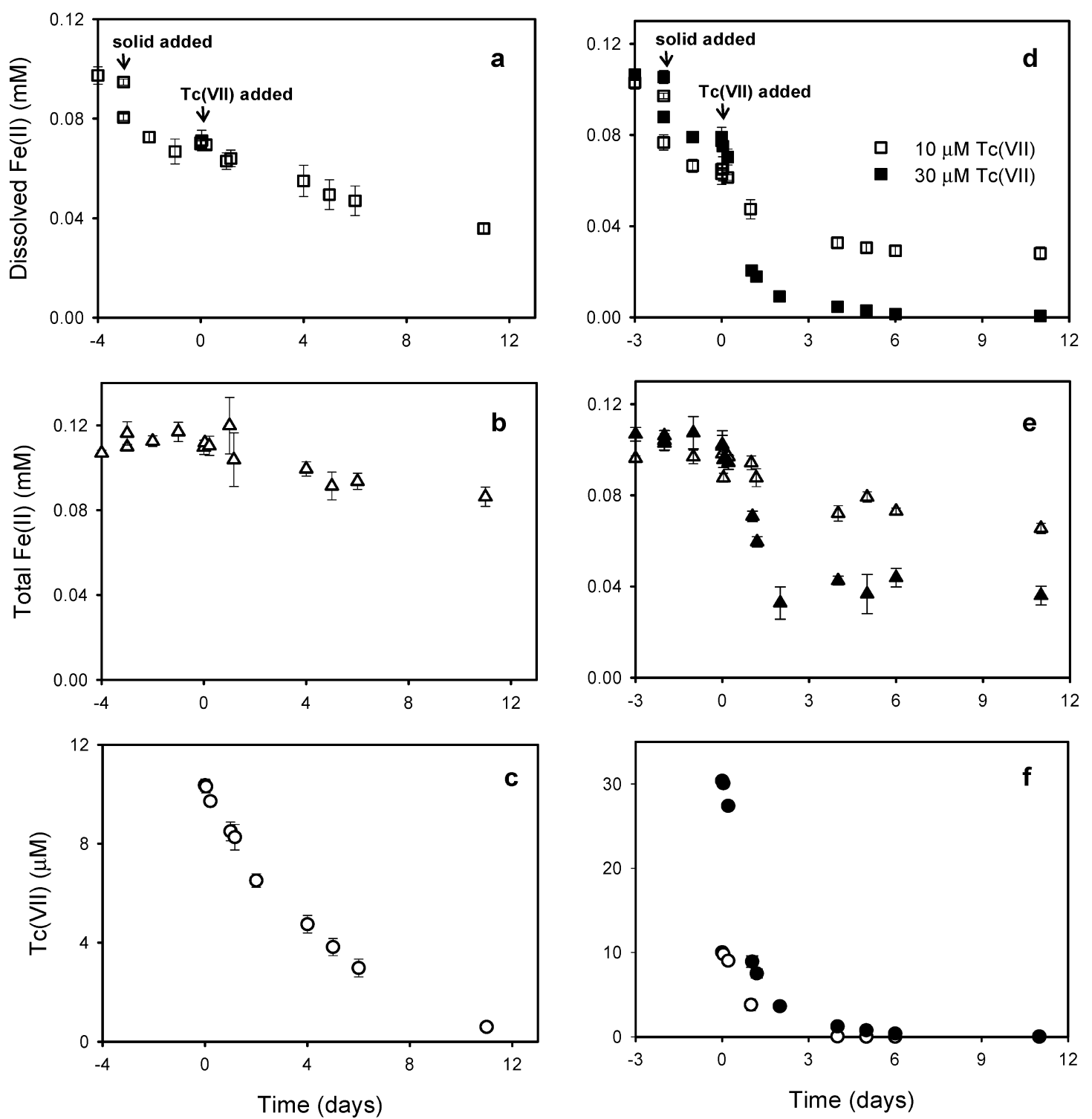

FIGURE 1. Time-dependent behavior of Fe(II) solutions spiked sequentially with diaspore $[5 \mathrm{~g} / \mathrm{L}]$ or corundum [3 $\mathrm{g} / \mathrm{L}]$ and $\mathrm{Tc}(\mathrm{VII})$ for pH 7: (a) dissolved $\mathrm{Fe}(\mathrm{II})\left[\mathrm{Fe}(\mathrm{II})_{\text {added }}=0.1 \mathrm{mM}\right]$ with diaspore, (b) total $\mathrm{Fe}(\mathrm{II})$ with diaspore, (c) dissolved $\mathrm{Tc}(\mathrm{VII})[\mathrm{Tc}(\mathrm{VIII})$ added $=10 \mu \mathrm{M}]$ with diaspore, (d) dissolved $\mathrm{Fe}$ (II) $\left[\mathrm{Fe}(\mathrm{II})_{\text {added }}=0.1 \mathrm{mM}\right]$ with corundum, (e) total $\mathrm{Fe}(\mathrm{II})$ with corundum, and (f) dissolved $\mathrm{Tc}(\mathrm{VII})$ $\left[\mathrm{Tc}(\mathrm{VII})_{\text {added }}=10\right.$ and $\left.30 \mu \mathrm{M}\right]$ with corundum. Arrows indicate times of solid and Tc(VII) additions. Data represent means ( \pm SD) of triplicate samples.

TABLE 2. Concentrations of $\mathrm{Tc}(\mathrm{VII})_{\mathrm{TPAC}^{a}}$, Total $\mathrm{Fe}(\mathrm{II})_{\text {calcd }}{ }^{b}$ and total $\mathrm{Fe}(\mathrm{II})_{\text {meas }}{ }^{c}$ at the End of $\mathrm{Tc}(\mathrm{VII})$ Reduction in Al(hydr)oxide Suspensions

$\begin{array}{ccc}\operatorname{Tc}(\mathrm{VII})_{\text {TPAC }}(\boldsymbol{\mu} \mathbf{M}) & \text { total Fe}(I I)_{\text {calcd }}(\mu \mathrm{M}) & \text { total Fe(II) })_{\text {meas }}(\mu \mathbf{M}) \\ 0.66 \pm 0.05 & 79.6 & 86.3 \pm 4.5 \\ 0.94 \pm 0.01 & 69.8 & 65.5 \pm 2.3 \\ 8.44 \pm 0.11 & 41.1 & 36.0 \pm 4.1\end{array}$

$5 \mathrm{~g} / \mathrm{L}$ diaspore, $0.1 \mathrm{mM}$ Fe(II), $10 \mu \mathrm{M} \mathrm{Tc}(\mathrm{VII})$

$3 \mathrm{~g} / \mathrm{L}$ corundum, $0.1 \mathrm{mM} \mathrm{Fe}(\mathrm{II}), 10 \mu \mathrm{M}$ Tc(VII)

$3 \mathrm{~g} / \mathrm{L}$ corundum, $0.1 \mathrm{mM}$ Fe(II), $30 \mu \mathrm{M}$ Tc(VII)

$$
8.44 \pm 0.11
$$

${ }^{a} \mathrm{Tc}(\mathrm{VII})_{\mathrm{TPAC}}-\mathrm{Tc}(\mathrm{VII})$ extracted by TPAC from the acidified suspensions ( $24 \mathrm{~h} 0.5 \mathrm{M} \mathrm{HCl}$ extraction). ${ }^{b}$ Total Fe(II) $)_{\text {calcd }}=$ $[\mathrm{Fe}(\mathrm{II})]_{\text {initial }}-3[\mathrm{Tc}(\mathrm{VII})]_{\text {reduced }}+3[\mathrm{Tc}(\mathrm{VII})]_{\mathrm{TPAC}}{ }^{c}$ Total $\mathrm{Fe}(\mathrm{II})_{\text {meas }}$ - total Fe(II) concentration by the end of Tc(VII) reduction (Figure 1b, e).

The time-variant loss of Tc(VII) from solution by heterogeneous reduction displayed a linear relationship $\ln \left(C_{t} /\right.$ $C_{0}$ ) versus time. The reduction rate of $\mathrm{Tc}(\mathrm{VII})$ was consequently described by a first-order kinetic law with a pseudofirst-order rate constant, $k_{o b s}$ (Table 1 ). We found dramatically slower reduction kinetics in the presence $\mathrm{Al}$ (hydr)oxides than $\mathrm{Fe}(\mathrm{III})$ (hydr)oxides (hematite, goethite) at similar chemical conditions [e.g., pH, total $\mathrm{Tc}(\mathrm{VII})$ and $\mathrm{Fe}(\mathrm{II})$ amounts, Table 1 (12)]. Although adsorbed Fe(II) concentra- tions were correspondingly lower on diaspore and corundum than on isostructural goethite and hematite under comparable conditions, reduction rates normalized to adsorbed $\mathrm{Fe}(\mathrm{II})$ were still lower for the $\mathrm{Al}$ (hydr) oxides (Table 1). These results indicate fundamental differences in kinetic reactions for surface-complexed Fe(II) on the two oxide types. The reduction rates obtained in this work were also slower than those found for bioreduced sediments in which biogenic $\mathrm{Fe}(\mathrm{II})(1-4 \mathrm{mM})$ was primarily sorbed (mechanism unde- 
fined) by residual solid phases in the sediment [presumed to be Fe(III) oxides (7)].

Mössbauer Spectroscopy. Mössbauer spectra were obtained at room temperature (RT) and $20 \mathrm{~K}$ for adsorbed ${ }^{57} \mathrm{Fe}(\mathrm{II})$ and for Tc/Fe "precipitates" on corundum with 10 and 30 $\mu \mathrm{M}$ Tc(VII).

The RT and $20 \mathrm{~K}$ Mössbauer spectra of adsorbed ${ }^{57} \mathrm{Fe}(\mathrm{II})$ displayed an asymmetric doublet attributed to Fe(II) [93-95\%] and $\mathrm{Fe}(\mathrm{III})$ [5-7\%] (Figure 2a, f). The spectral contribution of $\mathrm{Fe}(\mathrm{III})$ resulted from $\mathrm{Fe}$ (III) impurities in corundum. The total Fe concentration in the bulk corundum as determined by dissolution in concentrated $\mathrm{H}_{2} \mathrm{SO}_{4}, \mathrm{HCl}$, and $\mathrm{HNO}_{3}$ was $92 \pm 7 \mu \mathrm{g} / \mathrm{g}\left(2 \mu \mathrm{g} / \mathrm{g}{ }^{57} \mathrm{Fe}\right.$, natural ${ }^{57} \mathrm{Fe}$ abundance $\left.=2.12 \%\right)$ or $5 \%$ of the total amount of ${ }^{57} \mathrm{Fe}$ adsorbed to the corundum surface (Figure 1d).

The redox reaction of $\mathrm{Tc}(\mathrm{VII})$ with adsorbed Fe(II) caused significant changes in the Mössbauer spectra of ${ }^{57} \mathrm{Fe}$ (Figure 2). These changes were different for the two Tc(VII) treatments [10 and $30 \mu \mathrm{M}$ ] where approximately $30 \%$ and $90 \%$ of the total Fe(II), respectively, was oxidized (Figure 1e, Table 2). The $10 \mu \mathrm{M}$ Tc(VII) spectra at RT revealed the presence of a new Fe(III) doublet, along with the continued presence of the Fe(II) doublet with apparently unchanged Mössbauer parameters (Figure 2b). Consistent with the higher oxidant concentration, the $30 \mu \mathrm{M}$ Tc(VII) RT spectra showed almost complete conversion to a Fe(III) doublet with a small remaining Fe(II) signal (Figure 2c). A small, but significant and consistent fraction of the Fe(III) in both treatments magnetically ordered below $77 \mathrm{~K}$ (shown for $20 \mathrm{~K}$ only, Figure $2 \mathrm{e}-\mathrm{h}$ ) yielding sextet features. The magnetically ordered phase-displayed Mössbauer parameters [isomer shift $(\delta) 0.45$ $\mathrm{mm} / \mathrm{s}$, quadropole shift parameter $(\epsilon) 0.03 \mathrm{~mm} / \mathrm{s}$, and hyperfine field $\left(B_{\mathrm{hf}}\right) 53 \mathrm{~T}$ ] more similar to hematite than ferrihydrite (22). The spectral contribution of Fe(III) to the overall Fe signal was $40 \%$ (Figure $2 \mathrm{e}$ ) and $89 \%$ (not shown) for the 10 and $30 \mu \mathrm{M}$ Tc(VII) treatments, respectively, after accounting for background Fe(III) (5-7\%).

The nature of the sorbed Fe(II) oxidation product was not unique to Tc because reaction with $\mathrm{O}_{2(\mathrm{~g})}$ produced a surface phase with similar Mössbauer response (Figure 2h). The air oxidation product displayed a broadened Fe(III) doublet at RT (Figure 2d), with partial magnetic ordering at $20 \mathrm{~K}$ (Figure 2h). The apparent Mössbauer parameters of the sextet feature in the air-oxidized and Tc-reduced samples were virtually identical (Figure 2g,h). Moreover, this phase was found in similar total concentrations in all treatments: 0.021, 0.024, and $0.024 \mathrm{mM} \mathrm{Fe}(\mathrm{III})$ in the $10 \mu \mathrm{M}, 30 \mu \mathrm{M} \mathrm{Tc}(\mathrm{VII})$-reduced, and $\mathrm{O}_{2}$-oxidized samples, respectively. Approximately $4 \%$ $\mathrm{Fe}(\mathrm{II})$ remained in the sample after one week of air-oxidation (Figure 2d, h).

EXAFS Spectroscopy. XANES analyses demonstrated that Tc on the corundum surface was in the Tc(IV) valence state after reaction with adsorbed Fe(II) (Figure S2). Radial transforms of Tc-EXAFS data for 10 and $30 \mu \mathrm{M}$ Tc/Fe/ corundum precipitates were identical and similar to Tc(IV)corundum standards obtained by slow or fast titration (Figure 3a, Tc-EXAFS data are shown in Figure S3). The only difference between Tc/Fe/corundum samples and the standards was peak amplitude. Unlike results found for heterogeneous Tc(IV) on isostructural hematite (12), there was no evidence for Fe in the second coordination shell of Tc(IV) as indicated by absence of a distinctive peak at $2 \AA$. Radial transforms of all the Tc(IV) corundum samples were significantly different from $\mathrm{TcO}_{2} \cdot n \mathrm{H}_{2} \mathrm{O}_{(\mathrm{s})}$ produced by Tc(VII) reaction with dithionite (23).

The Tc(IV)-EXAFS data for the standards without Fe were interpreted with a model based on the $\alpha-\mathrm{Al}_{2} \mathrm{O}_{3}(0001)$ surface (24). This surface differs from 0001 on hematite (25) in that it is dominated by surface oxygens that are coordinated to two $\mathrm{Al}$ atoms. A monomeric, edge-sharing surface complex of $\mathrm{Tc}-\mathrm{O}$ octahedra with two $\mathrm{Al}$ second shell neighbors is expected as the most simple surface configuration. This model was implemented, and it did not provide good fits to the EXAFS data for the Tc(IV)-corundum standards because the second shell (e.g., spectral region of 1.9 to $2.8 \AA$ ) was not well explained with only $\mathrm{Al}$ atoms. Allowing for the possibility of Tc-O-Tc bonding [as described in refs 9 and 12] as dimers, longer chains attached to the surface, or as some fraction of surface-associated $\mathrm{TcO}_{2} \cdot n \mathrm{H}_{2} \mathrm{O}$ particles (not really distinguishable by EXAFS) provided much better fits to the secondshell spectral region (Figure $3 \mathrm{~b}$, Table S1). Indeed, Tc-Tc bonding dominated the second-shell response. The fits for both standards yielded an average number of Tc-Tc bonds per Tc as 1.3-1.8, which is below that for pure $\mathrm{TcO}_{2} \cdot n \mathrm{H}_{2} \mathrm{O}$ precipitate. This number and the $\mathrm{Tc}-\mathrm{Al}$ parameters tended to have large error bars since the $\mathrm{Al}$ contribution was weak (Table S1). Addition of the multiple scattering from the Tc-O octahedra allowed qualitative description of the third-shell spectral region $(2.8-3.7 \AA$ ) (Figure $3 \mathrm{~b})$.

The Tc(IV)-corundum model for the standards was applied to the two heterogeneous samples exposed to 10 and $30 \mu \mathrm{M}$ $\mathrm{Tc}(\mathrm{VII})$, and $0.1 \mathrm{mM} \mathrm{Fe}(\mathrm{II})$. Our modeling strategy was to first apply the standard model without change to the sample data and then to add second shell Fe(III) as necessary to improve fit. Second-shell Fe(III) was a dominant feature in the EXAFS of heterogeneous Tc(IV) precipitates on both ferrihydrite (9) and goethite/hematite (12) and was expected here. The model for the standards, however, provided semiquantitative simulations of the sample data (Figure 3c) without the addition of Fe(III) to the second shell (Table S1). The first shell amplitude increase is explained mainly by a smaller Debye-Waller factor (less disorder). Similarly, the amount of Tc-Tc bonding increased only slightly with most of the increase in second-shell amplitude because of smaller disorder. The primary features of the second and third shell were well described with second-shell Tc-Tc bonding and multiple scattering from $\mathrm{Tc}-\mathrm{O}$ octahedral alone. While bonds with Fe could be added to account for the small difference at larger distances not described by multiple scattering, it would be difficult to distinguish between "correct" models, and the ultimate contribution of Fe would be small. Overall, the EXAFS data were consistent with a surface Tc(IV) phase that exhibited lower second-shell coordination numbers than $\mathrm{TcO}_{2} \cdot n \mathrm{H}_{2} \mathrm{O}$, and a minimum of coreacted $\mathrm{Fe}(\mathrm{III})$.

\section{Discussion}

Reduction Reaction. Homogeneous Tc(VII) reduction by dissolved Fe(II) is slow although it is thermodynamically feasible over the Tc concentration range found in contaminated environments $(6,8,9)$. The overall reaction is

$3 \mathrm{Fe}^{2+}+\mathrm{TcO}_{4}^{-}+4 \mathrm{H}^{+} \leftrightarrow 3 \mathrm{Fe}^{3+}+\mathrm{TcO}(\mathrm{OH})_{2}+\mathrm{H}_{2} \mathrm{O}$

$$
\left(\Delta G_{\mathrm{r}}^{\circ}=54.5 \mathrm{~kJ}\right)
$$

where $\mathrm{TcO}(\mathrm{OH})_{2}$ is the dominant Tc(IV) dissolved species in non-complexing solutions over the $\mathrm{pH}$ range of 2-10 (26). Product Fe(III) hydrolyzes and precipitates at curcumneutral $\mathrm{pH}$ to complex mixed phases that complicate the thermodynamics of this reaction (9). Equation 4 indicates that reaction direction strongly depends on $\mathrm{pH}$ and concentrations of $\mathrm{Fe}$ and $\mathrm{Tc}$ aqueous species. For instance, we unexpectedly found that the backward reaction of Tc(IV) oxidation by dissolved Fe(III) was rapid under anoxic acidic conditions with low $\mathrm{Fe}$ (II) [Fe(II)/corundum suspension with $30 \mu \mathrm{M}$ Tc(VII), Figure 1]. To our knowledge, this is the first experimental evidence for Tc(IV) oxidation by dissolved $\mathrm{Fe}$ (III) under acidic conditions. The experimental work of Ben Said et al. (27) on $\mathrm{Tc}(\mathrm{VII})$ reduction by $\mathrm{Fe}(\mathrm{II})$ in $\mathrm{HCl}$ medium provides indirect evidence that the reaction is reversible and that $\mathrm{Tc}(\mathrm{IV})$ oxidation might occur. 

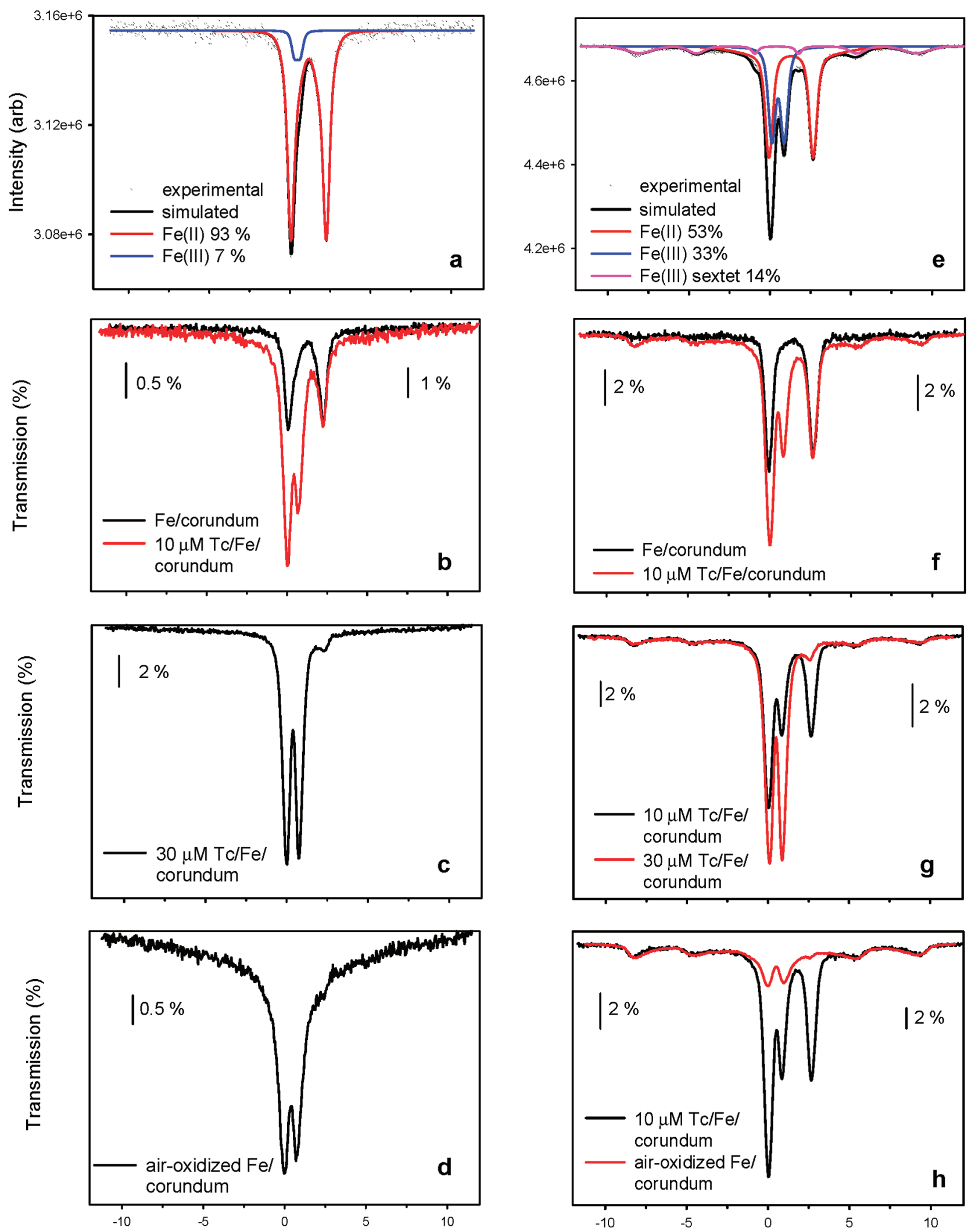

Velocity $(\mathrm{mm} / \mathrm{s})$

FIGURE 2. Room-temperature Mössbauer spectra of (a) Fe/corundum (experimental and simulated), (b) Fe/corundum shown together with $10 \mu \mathrm{M} \mathrm{Tc/Fe/corundum,} \mathrm{(c)} 30 \mu \mathrm{M} \mathrm{Tc/Fe/corundum,} \mathrm{and} \mathrm{(d)} \mathrm{air-oxidized} \mathrm{Fe/corundum.} \mathrm{Twenty} \mathrm{kelvin} \mathrm{Mössbauer} \mathrm{spectra} \mathrm{of} \mathrm{(e)}$ $10 \mu \mathrm{M} \mathrm{Tc/Fe/corundum} \mathrm{(experimental} \mathrm{and} \mathrm{simulated),} \mathrm{(f)} \mathrm{Fe/corundum} \mathrm{shown} \mathrm{together} \mathrm{with} 10 \mu \mathrm{M} \mathrm{Tc/Fe/corundum,} \mathrm{(g)} 10 \mu \mathrm{M} \mathrm{Tc/Fe/}$ corundum and $30 \mu \mathrm{M} \mathrm{Tc} / \mathrm{Fe} /$ corundum, and (h)10 $\mu \mathrm{M}$ Tc/Fe/corundum shown together with air-oxidized Fe/corundum.

Homogeneous Tc(VII) reduction is slow because of kinetic limitations $(8,9)$. An increase in both $\mathrm{pH}$ and $\mathrm{Fe}(\mathrm{II})$ concentration accelerates homogeneous $\mathrm{Tc}(\mathrm{VII})$ reduction.
Zachara et al. (9) showed that up to $30 \%$ of Tc(VII) $[10 \mu \mathrm{M}$ $\mathrm{Tc}(\mathrm{VII})$ initial] was homogeneously reduced within 3 days in the presence of $0.2 \mathrm{mM}$ Fe(II). Homogeneous reduction 

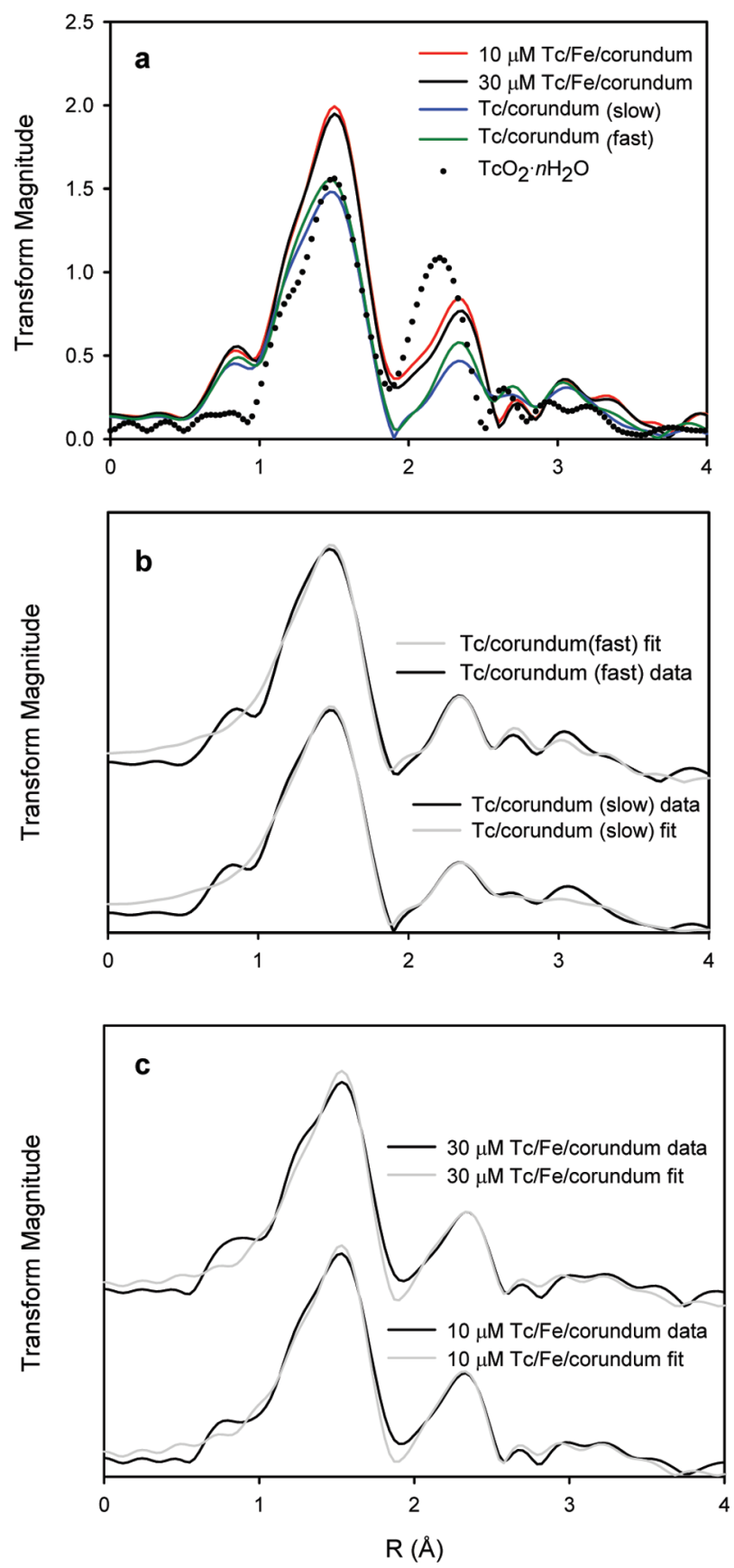

FIGURE 3. (a) Fourier transform radial distribution for $\mathrm{TcO}_{2} \cdot \mathrm{nH}_{2} \mathrm{O}$, slow and fast titrated Tc(IV)-corundum standards and heterogeneously precipitated Tc(IV) [10 and $30 \mu \mathrm{M}$ Tc(VII)] by $\mathrm{Fe}$ (II) adsorbed on corundum at $\mathrm{pH} 7$. Fourier transform radial distribution function and fitting results (b) for slow and fast titrated Tc(IV)-corundum standards and (c) for hetegeneously precipitated $10 \mu \mathrm{M} \mathrm{Tc}(\mathrm{VII})$ and $30 \mu \mathrm{M} \mathrm{Tc}(\mathrm{VII})$ by $\mathrm{Fe}$ (II) adsorbed on corundum at $\mathrm{pH}$ 7. Fourier transforms are not phase-shifted.

proceeded to a threshold dissolved Fe(III) concentration (eq 4), above which precipitation of complex, mixed Fe(III) / Fe(II) solid phases occurred. Precipitation enhanced further Tc(VII) reduction through $\mathrm{Fe}(\mathrm{II})$ adsorption and heterogeneous reaction.

The RT and $20 \mathrm{~K}$ Mössbauer measurements before and after Tc(VII) reduction showed significant difference in Fe speciation on the corundum surface. The Fe(II) doublet became less intense in the Tc-reduced samples and was accompanied by an increase in the Fe(III) doublet, and formation of a minor Fe(III) sextet at $20 \mathrm{~K}$. A majority of the surface Fe(III) did not magnetically order at $20 \mathrm{~K}$ and remained as a doublet. This lack of magnetic order implies the presence of a Fe(III) phase with short-range ordering (22) or the presence of adsorbed Fe(III) (28). The Mössbauer parameters for the $\mathrm{Fe}(\mathrm{III})$ sextet were close to those for hematite. Corundum is isostructural with hematite (29) and exhibits similar lattice parameters (30); consequently, heterogeneous oxidation of adsorbed Fe(II) on crystal growth sites could result in epitaxial hematite growth. The Mössbauer measurements demonstrated that the formation of a magnetically ordered Fe(III) fraction did not depend on the oxidant nature. Both $\mathrm{Tc}(\mathrm{VII})$ and $\mathrm{O}_{2}$ led to the formation of a virtually identical hematite-like phase of $\sim 20 \mu \mathrm{M}(\sim 6.7$ $\mu \mathrm{mol} / \mathrm{g}$ ) total concentration. Moreover, a decrease in the sorbed Fe concentration from $\sim 0.1 \mathrm{mM}[30 \mu \mathrm{M}$ Tc(VII)reduced sample] to $\sim 0.03 \mathrm{mM}$ [air-oxidized sample] had no effect on the Fe(III) sextet magnitude. These results suggested that multiple $\mathrm{Fe}$ (II) adsorption sites were present on the corundum surface and that those resultant in magnetic ordering of Fe(III) were filled first during Fe(II) adsorption. Overall, the Mössbauer data revealed the formation of at least two different $\mathrm{Fe}(\mathrm{III})$ phases on corundum: poorly ordered Fe(III) phases, adsorbed Fe(III), or both, and a hematite-like precipitate.

During Tc(VII) reduction, the concentration of adsorbed Fe(II) remained relatively constant, while the concentration of dissolved Fe(II) decreased in response to the stoichiometic demand generated at the surface. Continued adsorption apparently replenished the concentration of surface Fe(II) that was consumed by heterogeneous reduction. The Mössbauer measurements did not reveal any differences in Fe(II) doublet parameters before and after Tc(VII) reduction. It was surmised that $\mathrm{Fe}(\mathrm{II})$ that was resorbed during reduction occupied the same surface site type as the original reactant $\mathrm{Fe}(\mathrm{II})$. Given our past findings of mixed $\mathrm{Fe}(\mathrm{III})-\mathrm{Fe}(\mathrm{II})$ precipitates resulting from homogeneous reduction of Tc(VII) by $\mathrm{Fe}(\mathrm{II})_{(\mathrm{aq})}(9)$, we unexpectedly saw no evidence for $\mathrm{Fe}(\mathrm{II})$ adsorption to or coprecitation within the poorly ordered Fe(III) phases or hematite-like oxidation product. Reactive $\mathrm{Fe}(\mathrm{II})$ and product $\mathrm{Fe}(\mathrm{III})$ phases responded as distinct and separate entities to Mössbauer spectroscopy.

Tc(IV) Reaction Product. The Tc-EXAFS data implied the precipitation of a $\mathrm{TcO}_{2}$-like solid phase on corundum. Radial transforms of the Tc-EXAFS data for 10 and $30 \mu \mathrm{M}$ Tc(IV) on corundum were identical to each other and similar to Tc(IV)-corundum standards obtained by slow or fast hydrolysis that were intended to provide Tc(IV) in surface complexed state. $\mathrm{TcO}_{2}$-like precipitates were consequently produced by two very different preparation techniques: (i) $\mathrm{Tc}(\mathrm{VII})$ reduction by $\mathrm{Fe}(\mathrm{II})$ adsorbed on corundum at a fixed $\mathrm{pH} 7$ and (ii) hydrolysis of Tc(IV) - chloride complexes in the presence of corundum through $\mathrm{pH}$ increase from 0 to $\sim 7$. The gradual hydrolysis technique for the preparation of Tc(IV)-corundum standards was necessitated by the solubility of $\mathrm{TcO}_{2} \cdot n \mathrm{H}_{2} \mathrm{O}$, which does not increase to significant values until $\mathrm{pH}<1.5$.

Our heterogeneous Tc(IV) precipitate displayed similar EXAFS spectra to $\mathrm{TcO}_{2} \cdot n \mathrm{H}_{2} \mathrm{O}$ solids formed by microbial $\mathrm{Tc}(\mathrm{VII})$ reduction (3), Tc(IV) hydrolysis (31), electrochemical reduction (31), radiolysis (32), and reduction by magnetite, pyrite, or natural clay or sand samples (18). The Tc-EXAFS spectra of the $\mathrm{TcO}_{2}$-like precipitates on corundum were distinguished from pure $\mathrm{TcO}_{2} \cdot n \mathrm{H}_{2} \mathrm{O}$ reported in Figure 3a by significantly lower intensity and some phase shift in the second- and third-shell peaks. These differences were explained herein with a model that included the presence of dimers and larger polymeric Tc(IV) octahedral chains that reduced the average coordination number in the second shell to values below that of $\mathrm{TcO}_{2} \cdot n \mathrm{H}_{2} \mathrm{O}$. 
The proposed mechanism of $\mathrm{TcO}_{2} \cdot n \mathrm{H}_{2} \mathrm{O}$ formation involves Tc(IV) polymerization into soluble $\mathrm{Tc}_{n} \mathrm{O}_{y}{ }^{(4 n-2 y)+}$ chains that consequently precipitate into $\mathrm{TcO}_{2} \cdot n \mathrm{H}_{2} \mathrm{O}$ after some critical cluster size is attained $(18,31)$. The soluble polymeric $\mathrm{Tc}_{n} \mathrm{O}_{y}{ }^{(4 n-2 y)+}$ is found to be stable in acidic solutions with structure close to the solid $\mathrm{TcO}_{2} \cdot n \mathrm{H}_{2} \mathrm{O}$, confirming it to be a precursor for Tc(IV) oxide formation (31). The formation of the polymeric chains prior to $\mathrm{TcO}_{2} \cdot n \mathrm{H}_{2} \mathrm{O}$ precipitation might explain the similarity of Tc(IV) products prepared by two different techniques in our study and formation of the separate $\mathrm{TcO}_{2}$-like phase on corundum with few Tc-Fe bonds.

Other studies on Tc(VII) heterogeneous reduction performed in our laboratory show that the final Tc(IV) redox product depends on the nature of solid phase $(9,12)$. Pertechnetate reduction by Fe(II) adsorbed to Fe(III) oxides yielded octahedral Tc(IV) monomers and dimers attached to surface Fe (12). The marked difference in the Tc(IV) product nature between the isostructural Fe(III) oxide and $\mathrm{Al}$ oxide systems was unexpected and not easily explained. The products of homogeneous $\mathrm{Tc}(\mathrm{VII})$ reduction by $\mathrm{Fe}(\mathrm{II})$ also had more $\mathrm{Tc}-\mathrm{Fe}$ than Tc-Tc bondings, where Tc(IV) octahedral dimers were bound to Fe(III) associated with ferrihydrite structure (9). However, Tc(VII) reduction by Fecontaining phyllosilicates resulted in $\mathrm{TcO}_{2}$-like solid phase (12).

Published Tc-EXAFS spectra for Tc(IV) precipitates in anoxic sediments (6) and green rusts (16) have ambiguities in their fitted surface structures and vary with differences in total Tc(VII) concentration and Tc(VII):Fe(II) ratio. However, all results indicate that molecular speciation of the Tc(IV) redox product is influenced by the mineralogic nature of the solid-phase reductant. Important examples include Tc(IV) surface complexes on green rusts (16), $\mathrm{TcO}_{2} \cdot n \mathrm{H}_{2} \mathrm{O}$ (1), or Tc(IV) surface complexes associated with Fe centers (6) in anoxic sediments.

\section{Acknowledgments}

We thank Yuanxian Xia for his help in preparing Tc-corundum standards. The research was supported by the Environmental Remediation Sciences Program (ERSP), Office of Biological and Environmental Research (OBER), Environmental Remediation Sciences Division (ERSD), U.S. Department of Energy (DOE). Mössbauer spectroscopy measurements were performed in the Environmental Molecular Sciences Laboratory (EMSL) that is managed and supported by OBERERSD. PNNL is operated for the DOE by Battelle. PNC/XOR facilities at the Advanced Photon Source, and research at these facilities, are supported by he US Department of Energy Basic Energy Sciences, a major facilities access grant from NSERC, the University of Washington, Simon Fraser University, the Pacific Northwest National Laboratory and the Advanced Photon Source. Use of the Advanced Photon Source is also supported by the U.S. Department of Energy, Office of Science, Office of Basic Energy Sciences, under Contract DE-AC02-06CH11357.

\section{Supporting Information Available}

Details of Al (hydr)oxides characterization, analytical techniques and preparation of standards for XAS, figure showing Tc(VII) sorption kinetics to diaspore and corundum, figure showing XANES spectra of Tc/Fe/corundum precipitates, figure showing Tc-EXAFS spectra, and table with EXAFS fit parameters. This material is available free of charge via the Internet at http://pubs.acs.org.

\section{Literature Cited}

(1) Wildung, R. E.; Li, S. W.; Murray, C. J.; Krupka, K. M.; Xia, Y.; Hess, N. J.; Roden, E. E. Technetium reduction in sediments of a shallow aquifer exhibiting dissimilatory iron reduction potential. FEMS Microbiol. Ecol. 2004, 49, 151-162.

(2) Bondietti, E. A.; Francis, C. W. Geologic migration potentials of Tc-99 and Np-237. Science 1979, 203, 1337-1340.

(3) Wildung, R. E.; Gorby, Y. A.; Krupka, K. M.; Hess, N. J.; Li, S. W.; Plymale, A. E.; McKinley, J. P.; Fredrickson, J. K. Effect of electron donor and solution chemistry on products of dissimilatory reduction of technetium by Shewanella putrefaciens. Appl. Environ. Microbiol. 2000, 66, 2451-2460.

(4) Begg, J. D. C.; Burke, I. T.; Morris, K. The behaviour of technetium during microbial reduction in amended soils from Dounreay, U.K. Sci. Total Environ. 2007, 373, 297-304

(5) Abdelouas, A.; Grambow, B.; Fattahi, M.; Andres, Y.; LeclercCessac, E. Microbial reduction of ${ }^{99} \mathrm{Tc}$ in organic matter-rich soils. Sci. Total Environ. 2005, 336, 255-268.

(6) Burke, I. T.; Boothman, C.; Lloyd, J. R.; Mortimer, R. J. G.; Livens, F. R.; Morris, K. Effects of progressive anoxia on the solubility of technetium in sediments. Environ. Sci. Technol. 2005, 39, 4109-4116.

(7) Fredrickson, J. K.; Zachara, J. M.; Kennedy, D. W.; Kukkadapu, R. K.; McKinley, J. P.; Heald, S. M.; Liu, C. X.; Plymale, A. E. Reduction of $\mathrm{TcO}_{4}{ }^{-}$by sediment-associated biogenic $\mathrm{Fe}(\mathrm{II})$. Geochim. Cosmochim. Acta 2004, 68, 3171-3187.

(8) Cui, D. Q.; Eriksen, T. E. Reduction of pertechnetate by ferrous iron in solution: Influence of sorbed and precipitated $\mathrm{Fe}(\mathrm{II})$. Environ. Sci. Technol. 1996, 30, 2259-2262.

(9) Zachara, J. M.; Heald, S. M.; Jeon, B. H.; Kukkadapu, R. K.; Liu, C. X.; McKinley, J. P.; Dohnalkova, A. C.; Moore, D. A. Reduction of pertechnetate $[\mathrm{Tc}(\mathrm{VII})]$ by aqueous $\mathrm{Fe}(\mathrm{II})$ and the nature of solid phase redox products. Geochim. Cosmochim. Acta 2007, $71,2137-2157$.

(10) Stumm, W.; Sulzberger, B. The cycling of iron in natural environments-Considerations based on laboratory studies of heterogeneous redox processes. Geochim. Cosmochim. Acta 1992, 56, 3233-3257.

(11) Liger, E.; Charlet, L.; Van Cappellen, P. Surface catalysis of uranium(VI) reduction by iron(II). Geochim. Cosmochim. Acta 1999, 63, 2939-2955.

(12) Peretyazhko, T.; Zachara, J. M.; Heald, S. M.; Jeon, B.-H.; Kukkadapu, R. K.; Liu, C.; Moore, D.; Resch, C. T. Heterogeneous reduction of $\mathrm{Tc}(\mathrm{VII})$ by $\mathrm{Fe}(\mathrm{II})$ at the solid-water interface. Geochim. Cosmochim. Acta 2008, 72, 1521-1539.

(13) Cui, D. Q.; Eriksen, T. E. Reduction of pertechnetate in solution by heterogeneous electron transfer from $\mathrm{Fe}(\mathrm{II})$-containing geological material. Environ. Sci. Technol. 1996, 30, 2263-2269.

(14) Vandergraaf, T. T.; Ticknor, K. V.; George, I. M. Reactions between technetium in solution and iron-containing minerals under oxic and anoxic conditions. ACS Symp. Ser. 1984, 246, 25-43.

(15) Winkler, A.; Bruhl, H.; Trapp, C.; Bock, W. D. Mobility of technetium in various rocks and defined combinations of natural minerals. Radiochim. Acta 1988, 44-5, 183-186.

(16) Pepper, S. E.; Bunker, D. J.; Bryan, N. D.; Livens, F. R.; Charnock, J. M.; Pattrick, R. A. D.; Collison, D. Treatment of radioactive wastes: An X-ray absorption spectroscopy study of the reaction of technetium with green rust. J. Colloid Interface Sci. 2003, 268, 408-412.

(17) Lloyd, J. R.; Sole, V. A.; Van Praagh, C. V. G.; Lovley, D. R. Direct and $\mathrm{Fe}(\mathrm{II})$-mediated reduction of technetium by $\mathrm{Fe}$ (III)-reducing bacteria. Appl. Environ. Microbiol. 2000, 66, 3743-3749.

(18) Maes, A.; Geraedts, K.; Bruggeman, C.; Vancluysen, J.; Rossberg, A.; Hennig, C. Evidence for the interaction of technetium colloids with humic substances by X-ray absorption spectroscopy. Environ. Sci. Technol. 2004, 38, 2044-2051.

(19) Williams, A. G. B.; Scherer, M. M. Spectroscopic evidence for $\mathrm{Fe}(\mathrm{II})-\mathrm{Fe}$ (III) electron transfer at the iron oxide--water interface. Environ. Sci. Technol. 2004, 38, 4782-4790.

(20) Silvester, E.; Charlet, L.; Tournassat, C.; Gehin, A.; Greneche, J. M.; Liger, E. Redox potential measurements and Mossbauer spectrometry of $\mathrm{Fe}(\mathrm{II})$ adsorbed onto $\mathrm{Fe}(\mathrm{III})$ (oxyhydr)oxides. Geochim. Cosmochim. Acta 2005, 69, 4801-4815.

(21) Colon, D.; Weber, E. J.; Anderson, J. L. QSAR study of the reduction of nitroaromatics by $\mathrm{Fe}(\mathrm{II})$ species. Environ. Sci. Technol. 2006, 40, 4976-4982.

(22) Murad, E.; Cashion, J. Mossbauer Spectroscopy of Environmental Materials and Their Industrial Utilization; Kluwer Academic Publisher: Dordrecht, 2004.

(23) Hess, N. J.; Xia, Y. X.; Rai, D.; Conradson, S. D. Thermodynamic model for the solubility of $\mathrm{TcO}_{2} \cdot x \mathrm{H}_{2} \mathrm{O}_{(\mathrm{am})}$ in the aqueous Tc(IV)$\mathrm{Na}^{+}-\mathrm{Cl}^{-}-\mathrm{H}^{+}-\mathrm{OH}^{-}-\mathrm{H}_{2} \mathrm{O}$ system. J. Solution Chem. 2004, 33, $199-226$. 
(24) Eng, P. J.; Trainor, T. P.; Brown, G. E.; Waychunas, G. A.; Newville, M.; Sutton, S. R.; Rivers, M. L. Structure of the hydrated $\alpha-\mathrm{Al}_{2} \mathrm{O}_{3}$ (0001) surface. Science 2000, 288, 1029-1033.

(25) Trainor, T. P.; Chaka, A. M.; Eng, P. J.; Newville, M.; Waychunas, G. A.; Catalano, J. G.; Brown, G. E. Structure and reactivity of the hydrated hematite (0001) surface. Surf. Sci. 2004, 573, 204-224.

(26) Rard, J. A.; Rand, M. H.; Anderegg, G.; Wanner, H. Chemical Therodynamics of Technetium; Elsevier: Amsterdam, 1999.

(27) Ben Said, K.; Fattahi, M.; Musikas, C.; Delorme-Hiver, A.; Abbe, J. C. A novel approach to the oxidation potential of the Tc(VII)/ $\mathrm{Tc}$ (IV) couple in hydrochloric acid medium through the reduction of $\mathrm{TcO}_{4}^{-}$by $\mathrm{Fe}^{2+}$ ion. Radiochim. Acta 1998, 83, 195-203.

(28) Rancourt, D. G.; Thibault, P. J.; Mavrocordatos, D.; Lamarche, G. Hydrous ferric oxide precipitation in the presence of nonmetabolizing bacteria: constraints on the mechanism of a biotic effect. Geochim. Cosmochim. Acta 2005, 69, 553-577.
(29) Cornell, R. M.; Schwertmann, U. The Iron Oxides: Structure, Properties, Reactions, Occurrences, and Uses; Wiley-VCH: New York, 2003.

(30) Yamaguchi, I.; Terayama, T.; Manabe, T.; Tsuchiya, T.; Sohma, M.; Kumagai, T.; Mizuta, S. Preparation of (111)-oriented epitaxial $\mathrm{Fe}_{3} \mathrm{O}_{4}$ films on $\alpha-\mathrm{Al}_{2} \mathrm{O}_{3}(0001)$ substrates by coatingpyrolysis process using postepitaxial topotaxy via (0001)oriented $\alpha-\mathrm{Fe}_{2} \mathrm{O}_{3}$. J. Solid State Chem. 2002, 163, 239-247.

(31) Vichot, L.; Ouvrard, G.; Montavon, G.; Fattahi, M.; Musikas, C.; Grambow, B. XAS study of technetium(IV) polymer formation in mixed sulphate/chloride media. Radiochim. Acta 2002, 90, 575-579.

(32) Lukens, W. W.; Bucher, J. J.; Edelstein, N. M.; Shuh, D. K. Products of pertechnetate radiolysis in highly alkaline solution: Structure of $\mathrm{TcO}_{2} \cdot \mathrm{H}_{2} \mathrm{O}$. Environ. Sci. Technol. 2002, 36, 1124-1129.

ES8003156 